\title{
Epidemiology of constipation in adults: Why estimates of prevalence differ
}

\author{
Barry L. Werth* \\ Sydney Nursing School, University of Sydney, Sydney, Australia
}

Received: December 26, 2018

Accepted: January 22, 2019

Online Published: January 29, 2019

DOI: $10.5430 /$ jer.v5n $1 \mathrm{p} 37$

URL: https://doi.org/10.5430/jer.v5n1p37

\begin{abstract}
This review of over 80 articles published in the last 30 years shows that estimates of the prevalence of chronic constipation in community-dwelling adults varied widely from $2.4 \%$ to $39.6 \%$ in general adult populations and from $4 \%$ to $25.8 \%$ in older adult populations. Estimates of the prevalence of any constipation (including both chronic and sporadic constipation) also varied widely from $2.6 \%$ to $31.0 \%$ in general adult populations and from $4.4 \%$ to $44.5 \%$ in older adult populations. Apart from any country or regional differences, this wide range of estimated prevalence may be attributed to different definitions used for both chronic and any constipation as well as different data collection methods and sampling differences. Sampling issues include sample size, representativeness and age range of populations sampled. Further research is required to examine the impact of different definitions on prevalence estimates to help determine the best definitions for use in future epidemiological studies. If standard definitions can be universally agreed and used, along with appropriate sampling and data collection methods, more precise estimates of constipation prevalence should be attained. This would allow more meaningful comparisons between countries and may also provide the ability to pool results.
\end{abstract}

Key Words: Prevalence, Measurement, Adults, Constipation, Epidemiology

\section{INTRODUCTION}

Constipation is a common problem in the community. ${ }^{[1]} \mathrm{Be}-$ cause constipation represents a substantial financial burden due to the associated costs of diagnosis and treatment, and may have a considerable impact on quality of life, ${ }^{[2]}$ it is important to understand its prevalence in the community. However, constipation is largely self-diagnosed and its prevalence is difficult to gauge. Many studies have attempted to estimate the prevalence of constipation in communitydwelling adult populations and a wide range of estimates have been reported. ${ }^{[3,4]}$ This wide range of estimates makes it challenging to determine the true prevalence. It is important to understand the reasons why prevalence estimates vary so much and to consider how epidemiological studies could be improved to minimize variance, but there appears to be very little published about these issues in the literature.

The prevalence of constipation ranges widely between countries. ${ }^{[3]}$ Country-specific factors such as dietary and cultural factors may partly explain this variance but individual studyspecific factors relating to aspects of study design may also contribute to this variance, complicating any comparisons of countries and making it impossible to pool data. One factor is the use of different definitions of constipation. There appears to be no universal definition of constipation used in research although distinction is often made between chronic constipation and any constipation, the latter including both

\footnotetext{
*Correspondence: Barry L. Werth; Email: bwer8557@uni.sydney.edu.au; Address: Sydney Nursing School, University of Sydney, Sydney, 2006,
} Australia.

Published by Sciedu Press 
chronic and sporadic constipation. For chronic constipation, the symptom-based Rome criteria has been internationally recognized as the gold standard definition since 1994 (Rome 1). The criteria were revised in 2000 (Rome II), 2006 (Rome III) and 2016 (Rome IV) (see Table 1). ${ }^{[5]}$ Prior to 1994, definitions were largely based on bowel motion (BM) frequency but it was not always clear if it was chronic or any constipation. For any constipation, various other definitions have been used, the most common being self-reported and self-defined constipation within a specified time period.

Table 1. Rome diagnostic criteria for chronic constipation

\begin{tabular}{|c|c|c|c|}
\hline Rome I & Rome II & Rome III & Rome IV \\
\hline $\begin{array}{l}\text { Either two or more of the } \\
\text { following complaints present } \\
\text { for at least } 12 \text { months: } \\
\text { 1. Straining on at least } 25 \% \text { of } \\
\text { bowel movements when not } \\
\text { taking laxatives } \\
\text { 2. Feeling of incomplete } \\
\text { evacuation after at least } \\
\text { 25\%of bowel movements } \\
\text { when not taking laxatives } \\
\text { 3. Hard or pellet stools on at } \\
\text { least } 25 \% \text { of bowel } \\
\text { movements when not taking } \\
\text { laxatives } \\
\text { 4. Stools less frequent than } 3 \\
\text { per week without laxatives } \\
\text { Or } \\
\text { Fewer than two bowel } \\
\text { movements per week on } \\
\text { average, present for at least } 12 \\
\text { months }\end{array}$ & $\begin{array}{l}\text { At least } 12 \text { weeks, which need } \\
\text { not be consecutive, in the } \\
\text { preceding } 12 \text { months of two or } \\
\text { more of: } \\
\text { 1. Straining }>1 / 4 \text { of } \\
\text { defaecations } \\
\text { 2. Lumpy or hard stools }>1 / 4 \\
\text { of defaecations } \\
\text { 3. Sensation of incomplete } \\
\text { evacuation }>1 / 4 \text { of } \\
\text { defaecations } \\
\text { 4. Sensation of anorectal } \\
\text { obstruction/blockage }>1 / 4 \\
\text { of defaecations } \\
\text { 5. Manual manoeuvres to } \\
\text { facilitate }>1 / 4 \text { of } \\
\text { defaecations (e.g. digital } \\
\text { evacuation, support of the } \\
\text { pelvic floor) and/or } \\
\text { 6. <3 defaecations per week. } \\
\text { Loose stools are not present, } \\
\text { and there are insufficient } \\
\text { criteria for irritable bowel } \\
\text { syndrome. }\end{array}$ & $\begin{array}{l}\text { Diagnostic criteria* } \\
\text { 1. Must include two or more of } \\
\text { the following: } \\
\text { a. Straining during at least } 25 \% \\
\text { of defaecations } \\
\text { b. Lumpy or hard stools in at } \\
\text { least } 25 \% \text { of defaecations } \\
\text { c. Sensation of incomplete } \\
\text { evacuation for at least } 25 \% \\
\text { of defaecations } \\
\text { d. Sensation of anorectal } \\
\text { obstruction/blockage for at } \\
\text { least } 25 \% \text { of defaecations } \\
\text { e. Manual manoeuvres to } \\
\text { facilitate at least } 25 \% \text { of } \\
\text { defaecations (e.g. digital } \\
\text { evacuation, support of the } \\
\text { pelvic floor) } \\
\text { f. Fewer than } 3 \text { defaecations } \\
\text { per week. } \\
\text { 2. Loose stools are rarely present } \\
\text { without the use of laxatives } \\
\text { 3. Insufficient criteria for } \\
\text { irritable bowel syndrome } \\
\text { *Criteria fulfilled for the last } 3 \\
\text { months with symptom onset at } \\
\text { least } 6 \text { months prior to diagnosis }\end{array}$ & $\begin{array}{l}\text { Diagnostic criteria* } \\
\text { 1. Must include two or more of } \\
\text { the following: } \\
\text { a. Straining during more than } \\
25 \% \text { of defaecations } \\
\text { b. Lumpy or hard stools } \\
\text { (BSFS 1-2) more than } 25 \% \\
\text { of defaecations } \\
\text { c. Sensation of incomplete } \\
\text { evacuation more than } 25 \% \\
\text { of defaecations } \\
\text { d. Sensation of anorectal } \\
\text { obstruction/blockage more } \\
\text { than } 25 \% \text { of defaecations } \\
\text { e. Manual manoeuvres to } \\
\text { facilitate more than } 25 \% \text { of } \\
\text { defaecations (e.g. digital } \\
\text { evacuation, support of the } \\
\text { pelvic floor) } \\
\text { f. Fewer than } 3 \text { spontaneous } \\
\text { bowel movements } \\
\text { a. per week. } \\
\text { 2. Loose stools are rarely } \\
\text { present without the use of } \\
\text { laxatives } \\
\text { 3. Insufficient criteria for } \\
\text { irritable bowel syndrome } \\
\text { *Criteria fulfilled for the last } 3 \\
\text { months with symptom onset at } \\
\text { least } 6 \text { months prior to diagnosis }\end{array}$ \\
\hline
\end{tabular}

It is generally considered that constipation prevalence increases with age, particularly in older adults, and this has been demonstrated in a number of studies. ${ }^{[3]}$ There have been a considerable number of studies conducted in older adult populations but this subpopulation has not been reviewed separately in published global or regional reviews, nor have any reviews separated the types of constipation. It is important to distinguish between older adult populations and general adult populations, and to distinguish between chronic constipation and any constipation, when reviewing prevalence studies. This would provide a clearer understanding of the prevalence of constipation in community-dwelling adults.
The aim of this review is to report the prevalence of both chronic constipation and any constipation in communitydwelling adult and older adult populations. In particular, the review seeks to explain why prevalence estimates vary so widely in the literature.

\section{Methods}

A search of literature published in the period 1988 to 2018 was conducted. The search was conducted using Medline and Embase, as well as searching the references of articles retrieved, and was limited to human studies and English language articles. The following key search terms were used: constipation, prevalence, epidemiology. The search was limited to epidemiological studies which reported or described 
the prevalence of constipation in community-dwelling adult and older adult populations. Review articles were included but studies conducted in other subpopulations such as females and males were excluded, as were studies where the sample size was fewer than 100 participants. Titles and abstracts of articles were initially reviewed to determine if a study was eligible for further consideration. Eligible articles were then reviewed in full to ensure that the inclusion criteria were met. Articles meeting the criteria were segmented into general adult and older adult populations based on the age range of the sample. Because the definition of the term "el- derly" is not always agreed, ${ }^{[6]}$ this review has used the term "older adults" which refers to populations over the age of 50 years, as a subpopulation of the general adult population. The articles regarding general adult populations were grouped into five geographical regions. All studies were subdivided into chronic constipation and any constipation according to the definition of constipation used in the study. Studies included in the systematic reviews were also included with the individual studies but only if they met the inclusion criteria of this review.

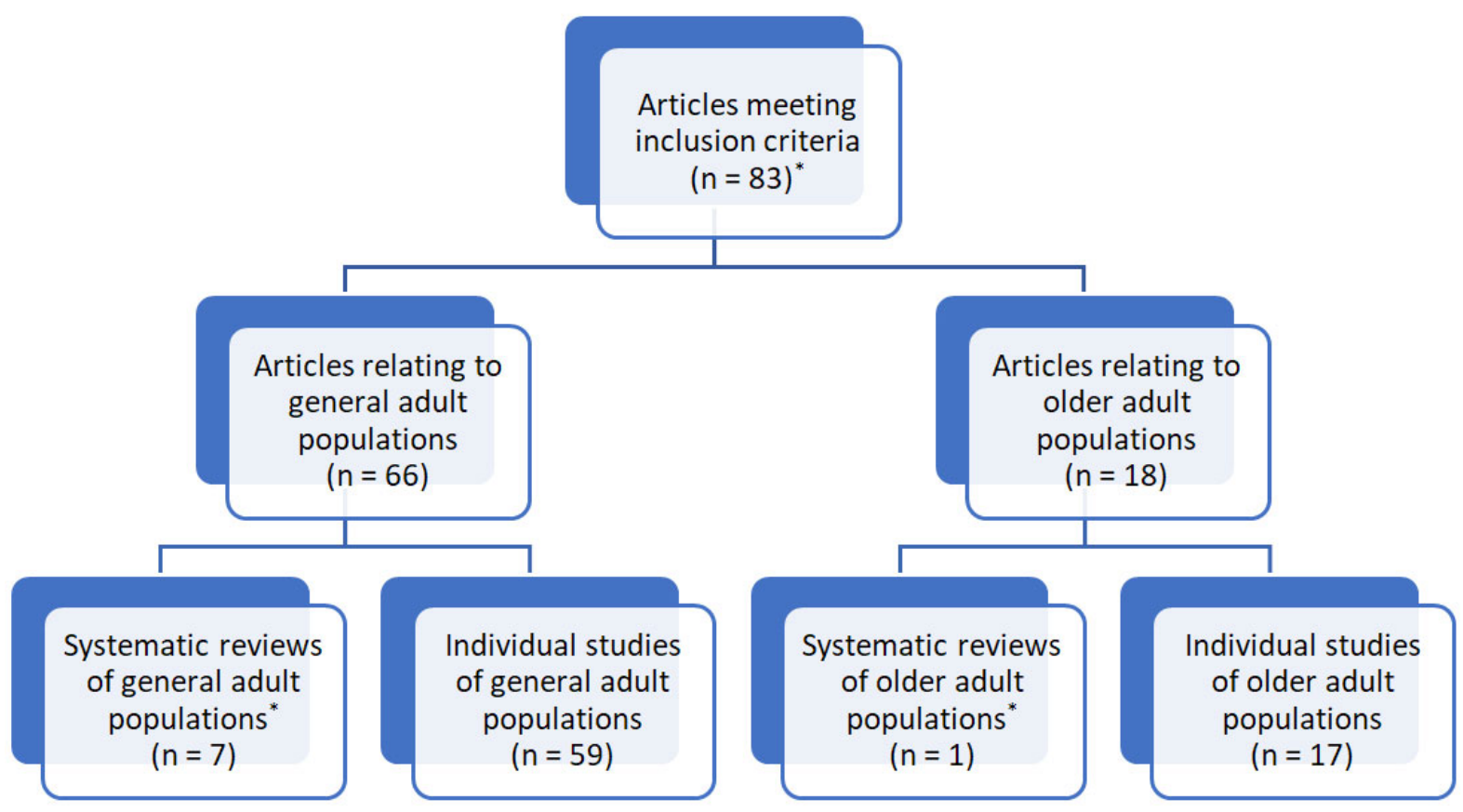

Figure 1. Results of search

* One article was a systematic review which separated general adult and older adult populations

\section{SeArCh ReSults}

Eighty-three articles met the inclusion criteria (see Figure 1). Of these, 7 were systematic reviews and 76 were individual studies of which 59 were studies of general adult populations and 17 were of older adult populations. In 7 studies, the prevalence of constipation was not stated but was able to be calculated from the published data. Three systematic reviews were global, two related to specific regions and two related to specific countries; one country review included reviews of both general adult and older adult populations.

\section{Prevalence of Constipation}

\subsection{Prevalence estimates in general adult populations 4.1.1 Global prevalence}

In the individual studies included in this review, the prevalence of chronic constipation ranged from $2.4 \%$ to $39.6 \%$, and the prevalence of any constipation ranged from $2.6 \%$ to $31.0 \%$ (see Table 2). A global systematic review and meta-analysis of 41 studies published up to 2010 found that the prevalence of chronic constipation ranged from $2.4 \%$ to $35 \%$ and the pooled prevalence was $14 \% .{ }^{[4]}$ Because various definitions were used in the studies reviewed including self-report and different Rome criteria, it is not valid to pool prevalence rates when different definitions have been used in different studies. ${ }^{[7]}$ Two other global reviews did not pool data from studies using different definitions. A systematic review of 50 population-based studies published from 1966 to 2010 reported that the prevalence of any constipation in adult populations ranged from $2.5 \%$ to $39.6 \% .^{[3]}$ A third global review of only 11 studies of adult populations published from 2005 to 2011 reported that the prevalence of any constipation ranged from $2.6 \%$ to $26.9 \%$. ${ }^{[8]}$ 


\subsubsection{North America}

Ten North American studies conducted from 1964 to 2000 were included in a systematic review. ${ }^{[9]}$ Data collection methods varied: 5 studies used mail surveys, ${ }^{[10-14]} 4$ studies used face-to-face interviews ${ }^{[15-18]}$ and one used a phone survey. ${ }^{[19]}$ Various definitions were used to assess constipation including self-report and different Rome criteria; prevalence rates ranged from $1.9 \%$ in a US study published prior to $1988^{[10]}$ to $27.2 \%$ in a Canadian study published in $2000 .^{[14]}$ An average prevalence of $14.8 \%$ was calculated however this may not be valid because of the different definitions and data collection methods. ${ }^{[7]}$ Since publication of the systematic review, nine more studies using various definitions have been located. ${ }^{[20-28]}$ The lowest prevalence of $3.1 \%$ was calculated using a definition of $<3 \mathrm{BM} /$ week $^{[24]}$ whilst the highest prevalence of $31.0 \%$ was based on self-report of chronic constipation during the past 12 months. ${ }^{[25]}$ Again, various data collection methods were used including mail surveys, phone and face-to-face interviews as well as internet surveys. The populations sampled also varied from predominantly Caucasian (e.g. Olmsted County in Minnesota) to general US adult populations in national surveys. Only one recent study claims to have used a large nationally representative sample. ${ }^{[26]}$ In addition to these studies, a longitudinal study of constipation has been conducted in the USA. First published in 2007 using 12 years of data from Olmsted County and modified Rome II criteria, the researchers found the prevalence at baseline to be $4.3 \%$ and 12 years later to be $4.1 \% .^{[29]}$ In 2012, 20 years of data were published and it was found that $3 \%$ had persistent chronic constipation and $21 \%$ had non-persistent chronic constipation. ${ }^{[30]}$

Table 2. Range of constipation prevalence estimates by region

\begin{tabular}{llllll}
\hline Region & $\begin{array}{l}\text { Number of studies/ } \\
\text { countries }\end{array}$ & \multicolumn{2}{l}{ Chronic constipation } & Any constipation \\
\hline General adult & 68 & Lowest \% & Highest \% & Lowest \% & Highest \% \\
populations & 19 & 3.6 & 19.4 & 3.5 & 31.0 \\
North America & 20 & 4.1 & 39.6 & 2.6 & 29.8 \\
Europe & 16 & 2.4 & 28.0 & 3.9 & 28.4 \\
Asia & 5 & - & 14.6 & 9.7 & 21.7 \\
South America & 8 & 2.8 & 30.7 & 6.3 & 9.2 \\
Australasia & 17 & Lowest \% & Highest \% & Lowest \% & Highest \% \\
Older adult & 7 & 5.7 & 24.4 & 4.7 & 44.5 \\
populations & 2 & - & 24.4 & 4.4 & 13.8 \\
North America & 3 & 4 & 25.8 & - & 16.5 \\
Europe & 1 & - & - & 13.8 & 42.9 \\
Asia & 4 & - & 16.9 & & 22.0 \\
Africa & & & &
\end{tabular}

\subsubsection{Europe}

A systematic review of studies published from 1986 to 2006 included 7 studies in general adult populations of 5 countries (France, Spain, Sweden, Norway \& Italy). ${ }^{[31]}$ Two studies used face-to-face interviews, ${ }^{[32,33]}$ four studies used a mailed questionnaire $^{[35-37]}$ and one study was prospective using a daily diary. ${ }^{[38]}$ It was found that the average prevalence of constipation was $17.1 \%$; however, because various definitions were used to assess constipation including self-report and Rome criteria, and different data collection methods were used, calculation of average prevalence lacks validity. ${ }^{[7]}$ Prevalence rates ranged from $5 \%$ when defined as $<3 \mathrm{BM} /$ week $^{[38]}$ to $29.5 \%$ with self-reported constipation. ${ }^{[37]}$ Including the studies in the systematic review, 17 studies of general adult populations conducted in 11 European coun- tries were located. ${ }^{[24,30-45]}$ Prevalence estimates ranged from $2.6 \%{ }^{[40]}$ to $39.6 \%^{[42]}$ with the highest estimate being for chronic constipation (see Table 2 ). A variety of constipation definitions have been used as well as various data collection methods, sample sizes and sample age ranges. Within each country, different studies have produced different results. This is mainly due to different definitions which have been used but it may also be due to different data collection methods, different age ranges and differences in the representativeness of the sample. For example, three studies have been conducted in Spain with results ranging from $4.1 \%$ to $29.5 \% \cdot{ }^{[35,44,45]}$ Each study used a different definition, different data collection method, different age range and only one study claimed to use a nationally representative sample. ${ }^{[45]}$ 
Table 3. Range of constipation prevalence estimates by factor in general adult populations

\begin{tabular}{|c|c|c|c|c|}
\hline Factor & Variable & $\begin{array}{l}\text { Number of } \\
\text { studies }\end{array}$ & $\begin{array}{l}\text { Lowest prevalence reported } \\
(\%)\end{array}$ & $\begin{array}{l}\text { Highest prevalence reported } \\
(\%)\end{array}$ \\
\hline \multirow{13}{*}{$\begin{array}{l}\text { Definition of } \\
\text { constipation }^{\wedge}\end{array}$} & $<3 B M /$ week & 6 & 2.7 & 17.4 \\
\hline & BSC & 1 & N/A & 7.2 \\
\hline & BSQ & 2 & 9.2 & 13.5 \\
\hline & GSQ & 2 & 3.9 & 7.3 \\
\hline & Rome I & 7 & 3.6 & 39.6 \\
\hline & Rome II & 16 & 2.8 & 30.7 \\
\hline & Rome III & 13 & 2.4 & 24.5 \\
\hline & Rome IV & 2 & 6.3 & 8.9 \\
\hline & Self-report (current) & 1 & N/A & 2.6 \\
\hline & Self-report (1 month) & 2 & 5.8 & 14.2 \\
\hline & Self-report (3 months) & 2 & 16.5 & 27.2 \\
\hline & Self-report (12 months) & 11 & 3.5 & 31.0 \\
\hline & Self-report (NTP) & 11 & 6.3 & 28.4 \\
\hline \multirow{6}{*}{$\begin{array}{l}\text { Data collection } \\
\text { method }^{\wedge}\end{array}$} & Face-to-face interview & 19 & 2.4 & 24.8 \\
\hline & Mail survey & 23 & 2.8 & 30.7 \\
\hline & Phone interview & 7 & 2.6 & 19.4 \\
\hline & Internet survey & 5 & 5.5 & 28.4 \\
\hline & Written questionnaire & 6 & 4.4 & 26.2 \\
\hline & Diary & 2 & 5.0 & 31.4 \\
\hline \multirow{8}{*}{$\begin{array}{l}\text { Age range } \\
\text { (years) }\end{array}$} & $\geq 15$ & 6 & 3.6 & 24.5 \\
\hline & $\geq 16$ & 3 & 2.4 & 7.3 \\
\hline & $\geq 18$ & 19 & 2.8 & 27.2 \\
\hline & $\geq 19$ & 1 & N/A & 4.4 \\
\hline & $\geq 20$ & 5 & 2.7 & 24.5 \\
\hline & $\geq 21$ or 25 & 2 & 16.8 & 31.0 \\
\hline & Various age ranges & 21 & 3.5 & 39.6 \\
\hline & No age range reported & 2 & 5.0 & 11.7 \\
\hline \multirow{6}{*}{ Sample size } & $100-499$ & 5 & 5.0 & 39.6 \\
\hline & $500-999$ & 13 & 2.8 & 24.8 \\
\hline & $1,000-1,999$ & 10 & 3.5 & 30.7 \\
\hline & $2,000-4,999$ & 14 & 4.4 & 26.2 \\
\hline & $5,000-9,999$ & 8 & 3.1 & 28.4 \\
\hline & $>10,000$ & 9 & 2.4 & 20.2 \\
\hline
\end{tabular}

Note. GSQ = Gastrointestinal Symptoms Questionnaire, BSQ = Bowel Symptoms Questionnaire, BSC = Bristol Stool Consistency Type 1 or 2, BM/week = Bowel movements per week, NTP = no time period specified, $\wedge$ More than one definition used in 12 studies, $\wedge$ More than one method used in 3 studies

\subsubsection{Asia}

A broad range of prevalence estimates has been reported in 15 studies conducted in 10 Asian countries which were located for this review. ${ }^{[24,46-59]}$ Prevalence estimates for chronic and any constipation ranged from $2.4 \%$ to $28.4 \%$ (see Table 2). This could be attributed to different cultures in different countries but it also may be the result of different definitions used as well as different data collection methods. In general, self-report definitions of any constipation yielded higher prevalence estimates than definitions of chronic constipation based on Rome criteria but this was not always the case - in one Japanese study they were very similar ${ }^{[46]}$ and in one Iranian study Rome II criteria yielded a much higher estimate than self-report. ${ }^{[55]}$ An example of different prevalence estimates using the same definition is found in two Korean studies. Both studies used Rome II criteria as the definition with similar sample sizes, each representative of the Korean population. The first study used a telephone survey of 1,029 subjects 15 years or older which resulted in a prevalence of $9.2 \%$ for chronic constipation using Rome II criteria. ${ }^{[51]}$ In the second study, face-to face interviews using a questionnaire based on Rome II criteria were conducted in 1,417 subjects. ${ }^{[52]}$ A prevalence of $2.6 \%$ was found for chronic constipation which was much lower than the previous study. This low result may have been because the ages of the subjects were restricted to 18 to 69 years and because the face-to-face interview lacked the relative anonymity of a telephone interview. 
A systematic review and meta-analysis of 15 prevalence studies conducted in China reported an overall prevalence of $8.2 \%$ in the general adult population. ${ }^{[60]}$ However, four of the studies included paediatric age groups within the adult populations studied so the result is not strictly of the adult population. In any case, the major problem with the metaanalysis is that four different definitions were used in the studies rendering calculation of an average invalid; ${ }^{[7]}$ nine studies used Rome II criteria, three used Rome III criteria, two used $<3 \mathrm{BM} /$ week and one used $<2 \mathrm{BM} /$ week. The average prevalence using Rome criteria was $6.9 \%$ compared to $13.4 \%$ in studies using bowel motion frequency but again it is not appropriate to calculate averages for different definitions. Nevertheless, this result is different to that reported for other countries where definitions based on bowel motion frequency generally yield lower prevalence values. Apart from any cultural differences, a possible explanation for this is the inclusion of paediatric age groups within four of the populations studied.

A systematic review of 10 studies conducted in Iranian adult populations showed that the prevalence of any constipation ranged from $1.4 \%$ to $37 \%$ and the prevalence of chronic constipation based on either Rome II or Rome III criteria ranged from $2.4 \%$ to $11.2 \% .^{[61]}$

\subsubsection{South America}

Four studies, ${ }^{[24,53,62,63]}$ have estimated prevalence in Brazil, Argentina and Colombia (see Table 2). In Brazil, prevalence ranged from $9.7 \%{ }^{[62]}$ when defined as $<3 \mathrm{BM} /$ week to $14.6 \%{ }^{[63]}$ when using modified Rome III criteria to $16.7 \%$ for self-reported constipation. ${ }^{\text {[24] }}$

\subsubsection{Australia}

Australia exemplifies the problem where a number of different studies in the same country have produced a wide range of prevalence estimates so it is difficult to determine the true prevalence (see Table 2). Eight studies of general adult populations were located, each surveying different populations and using different definitions. ${ }^{[64-71]}$ Consequently, estimates have from ranged from $2.8 \%$ to $30.7 \%$. Except for one study conducted in general practice clinics, all surveys were conducted by mail in population samples drawn from specific geographical regions which may not have been nationally representative.

A study using modified Rome III criteria (excluding the loose stools question) surveyed a convenience sample which was not nationally representative in general practices in Western Sydney and reported a prevalence of $8.1 \% .^{[64]}$ Other studies have been conducted in regional or urban areas using samples of adults aged 18 years or older. The most recent study used Rome III criteria and reported figures of $6.5 \%$ using strict criteria and $11.0 \%$ using modified criteria (excluding the requirement for 6 months onset of symptoms). ${ }^{[65]}$ An earlier study estimated prevalence of $9.2 \%$ using a symptombased questionnaire ( $<3 \mathrm{BM}$ per week or hard, lumpy stools or anal blockage) over a period of 3 months. ${ }^{[66]}$ Two other earlier studies used Rome I and Rome II criteria and reported prevalence estimates of $7.8 \%$ and $2.8 \%$ respectively ${ }^{[67,68]}$ whilst another two studies reported estimates of $6.3 \%$ and $13.5 \%$ using $<3 \mathrm{BM} /$ week over the last 12 months as the definition. ${ }^{[69,70]}$ In stark contrast to these estimates, a prevalence of $30.7 \%$ was reported using Rome II criteria in a study of community-dwelling adults in Sydney aged from 25 to 64 years. ${ }^{[71]}$ There are several possible reasons apart from the restricted age range which may explain this result. Firstly, the survey was conducted in a metropolitan population whereas others were conducted in regional areas. Also, although the bowel symptom questionnaire was based on Rome II criteria, it defined constipation differently. In this study, constipation was reported if there had been $<3 \mathrm{BM} /$ week, or hard/lumpy stools, or straining, or digital manipulation of stools, or incomplete evacuation experienced in the preceding 12 months. If this had been experienced often, or very often, or almost always during this period, it was recorded as a positive response. This definition is quite different to the strict Rome II criteria and is probably the main reason for the high estimate reported.

\subsection{Prevalence estimates in older adult populations}

Studies of older adult populations spanned 8 countries with seven studies conducted in US populations (see Table 2). ${ }^{[72-88]}$ The prevalence of chronic constipation has ranged widely from $4 \%$ in Indonesia ${ }^{[72]}$ to $25.8 \%$ in Korea. ${ }^{[73]}$ For any constipation, prevalence has ranged from $4.4 \%$ in Spain ${ }^{[74]}$ to $44.5 \%$ in the USA. ${ }^{[76]}$ Different definitions used in different studies are probably the major reason for this wide range although different populations, sample sizes and data collection methods may also contribute to these differences.

In a UK study, 596 elderly patients (aged over 65 years and registered in general practices) were interviewed faceto-face and it was found that, although $13.8 \%$ subjectively self-reported constipation (defined as their usual bowel habit with no time period specified), $24.4 \%$ had chronic constipation as per modified Rome II criteria. ${ }^{[77]}$ This result is the opposite of what is generally found - usually self-reported prevalence rates are higher than prevalence rates using Rome criteria. This is possibly because the interview process lacked anonymity and participants were less likely to admit to suffering constipation. Also, the different definition of self-report used in this study has no doubt influenced the result as well 
as the fact that modified Rome II criteria were used.

Three Australian studies have reported the prevalence of constipation in older populations with different results. In one study, patients attending general practices in a regional area completed a written questionnaire. ${ }^{[78]}$ The population consisted of 849 patients aged 65 years and older, almost all of whom $(95 \%)$ had used at least one medication for more than 6 months. It was found that $22 \%$ of patients selfreported having any constipation during the previous month. The constipation may or may not have been a side effect of medication that was being taken at the time since $54 \%$ of patients were taking 5 or more medicines. A longitudinal study of 239 subjects aged 65 years and older at baseline found that self-reported constipation increased from $13.8 \%$ to $20.9 \%$ over a period of 11 years. ${ }^{[79]}$ A more recent Australian study surveyed 236 subjects aged 65 years or older in Western Sydney and reported a prevalence of $16.9 \%$ for chronic constipation using modified Rome III criteria. ${ }^{[80]}$

In addition to the individual studies, a systematic review and meta-analysis of 7 Chinese studies has been published. ${ }^{[60]}$ Populations sampled were all 60 years or older except for one study sample which was 70 years or older. Five studies defined constipation as straining or hard stools or $<3 \mathrm{BM} /$ week, one study defined it as $<3 \mathrm{BM} /$ week and one study used Rome II criteria. The overall prevalence of constipation was $18.1 \%$ which was significantly higher than that calculated for the general population $(8.2 \%)$ although neither calculation is valid because of the different definitions used in the studies included in the review. ${ }^{[7]}$

\section{WHY PREVALANCE ESTIMATES DIFFER}

From the foregoing discussion it is evident that there are several possible explanations for the wide range of prevalence estimates.

\subsection{Country/region}

In studies reporting prevalence of chronic and any constipation, the intercontinental prevalence ranges are not dissimilar (see Table 2) although it has been shown that prevalence can often differ between individual countries. When comparing countries, any differences could be attributed to differences in culture, diet, environment, socioeconomic conditions and healthcare systems as well as genetic differences, ${ }^{[3]}$ however different constipation definitions, data collection methods and sampling make country comparisons difficult. One research group has conducted surveys in 11 countries using face-to-face interviews (except for two countries where telephone interviews were used) and using the same simple questionnaire which asked if constipation symptoms had been experienced during the prior year. ${ }^{[24,53]}$ In each country, the

Published by Sciedu Press sample size was 2,000 subjects, aged 15 years or older and representative of the country's population. Using the same definition, sample size and data collection method in each country, should ensure that data is consistent and enable comparisons between countries. This was the case in all countries except China where the sample size was 2,100 and subjects aged 60 years or more were excluded. The prevalence estimates ranged from $5.4 \%$ in Germany to $21.7 \%$ in Colombia.

\subsection{Definition of constipation}

A variety of different definitions of constipation have been used in the prevalence studies (see Tables 3 and 4). The gold standard definition of chronic constipation is the Rome criteria, the version of which varies depending on when the study was conducted. Some studies have used modified Rome criteria, particularly Rome III, either explicitly or surreptitiously. Not all studies have revealed exact details of the Rome criteria used or the questionnaire used so it has to be assumed that the strict criteria have been applied although this may not necessarily have been the case. It should be noted that prior to the publication of Rome II criteria in 1999, constipation as defined by Rome I would have included constipation-predominant irritable bowel syndrome (IBS-C). As a result, Rome I definitions tend to yield higher estimates than Rome II or III because of the non-exclusion of IBS$\mathrm{C}$ in the Rome I criteria. Most, but not all, studies using Rome II and Rome III criteria exclude IBS-C however there is significant overlap of symptoms so whether or not these are strictly distinct entities has been widely debated in the literature. ${ }^{[89-91]}$ Nevertheless, IBS-C may account for an additional 3 to $4 \%$ prevalence if included. ${ }^{[25,51,65]}$ For chronic constipation, Rome I and Rome II definitions tended to yield higher estimates than Rome III possibly because of the 12 months assessment period in Rome I and II definitions compared to 3 months with 6 months onset in Rome III, although eight of the Rome III studies have used modified criteria. The modifications have comprised not excluding IBS, not including the question about loose stools and not including the requirement of 6 months onset of symptoms. One study using Rome IV criteria reported low prevalence because the strict criteria were employed; conducted across USA, Canada and UK using nationally representative samples, the survey found the prevalence of chronic constipation to be $6.3 \%$ but, if irritable bowel syndrome and opioid-induced constipation were included, the prevalence would be $8.9 \% .^{[28]}$

Other studies have used self-report to estimate the prevalence of any constipation, which may include both sporadic and chronic constipation. In general, estimates of constipation prevalence using stool frequency (generally $<3 \mathrm{BM} /$ week) 
were consistently low and those using self-report were consistently high in the studies reviewed (see Tables 3 and 4). Most studies using self-report have allowed the participants to define constipation themselves, but some have defined constipation based on stool frequency and/or stool consistency, or have used some other criteria as the definition. Variations in prevalence using self-report can also be attributed to the different time periods that have been used with 12 months being the most common. A good illustration of the variance of self-report with different time periods was seen in a recent German study. ${ }^{[40]}$ Different time periods for self-reported constipation changed the prevalence estimate: $14.9 \%$ for 12 months, $5.8 \%$ for 4 weeks and $2.6 \%$ for current at the time of the survey.

In the majority of studies, the prevalence rates are considerably higher for any (self-reported) constipation compared to chronic constipation definitions based on Rome criteria. This is highlighted in a Spanish study where a questionnaire was mailed to adults aged 18 to 65 years, representative of the general population. ${ }^{[35]}$ Of the 349 respondents, $29.5 \%$ selfreported constipation in the prior year however this changed to $19.2 \%$ and $14 \%$ using Rome I and Rome II criteria respectively. Two other studies have similarly reported different prevalence estimates when comparing self-reported constipation to chronic constipation in the same sample. In Canada, $27.2 \%$ self-reported constipation in the prior 3 months however this changed to $16.7 \%$ and $14.9 \%$ using Rome I and Rome II criteria respectively. ${ }^{[14]}$ In Iran, 9.6\% self-reported constipation (no time period was specified), $4.4 \%$ reported $<3 \mathrm{BM}$ /week and $22.9 \%$ were constipated based on Rome II criteria - an unusual result which might be explained by the fact that the sample was 14 to 41 years old. ${ }^{[55]}$ No studies have investigated the full impact of different definitions on prevalence comparing bowel motion frequency, self-report and Rome III or IV definitions in the same general adult population sample.

\subsection{Data collection method}

The data collection method used may influence the survey outcome. Six different methods have been used to collect data in general adult population surveys, the most common being face-to-face interviews and mail surveys (see Table 3 ). The internet is being increasingly used for gastrointestinal research because it is cost effective and provides prompt data of high quality using representative population samples. ${ }^{\text {[92] }}$ Surveys conducted by mail or internet tend to report higher prevalence rates because participants provide data anonymously and do not experience the potential embarrassment of an interview. For this reason, interviews conducted faceto-face or by phone, and written questionnaires completed in clinics, tend to report lower prevalence rates.
The use of questionnaires (mail, phone, internet or face-toface) depends on the ability of participants to recall symptoms whereas the use of a daily diary does not rely on recall and therefore could be considered to be more credible. However, two prospective studies using a daily diary each showed quite different results - an Italian study ${ }^{[36]}$ using Rome II criteria reported a prevalence of $5 \%$ to $11 \%$ of individual symptoms but a Turkish study using Rome I criteria reported a prevalence of $31.4 \% .{ }^{[42]}$ Possible explanations for this difference may be because the latter used a one week diary and Rome I criteria whereas the Italian study used a four week diary and Rome II criteria.

The majority of studies in older populations (12 of the 17 studies) have used face-to-face interviews probably because this is the most reliable method of garnering information from older people (see Table 4). Phone interviews have not been used possibly because of potential hearing difficulties. Internet surveys have not been employed, no doubt because of potentially low response rates relating to computer illiteracy of older generations although this may change in time.

\subsection{Sample characteristics}

\subsubsection{Size}

A wide range of sample sizes have been used in prevalence studies with larger sample sizes tending to yield lower prevalence rates than smaller sample sizes. Most general adult population studies have used sample sizes from 2,000 to 5,000 (see Table 3). Smaller sample sizes (100 to 1,000) are more commonly used in surveys of older adult populations with 12 of the 17 studies using samples of fewer than 1,000 participants (see Table 4). This is possibly because overall older populations are of much smaller size than general adult populations. In both general adult and older adult surveys, sample size calculations have usually not been provided so it is not clear if the chosen sample sizes are appropriate.

\subsubsection{Representativeness}

Many general adult population surveys have used samples in regional areas rather than national surveys so the samples may not have been nationally representative. Several studies have shown that the prevalence of constipation can vary in regional areas within a country. ${ }^{[15,43,60]}$ Representativeness of samples is sometimes mentioned in studies of general adult populations but evidence is not provided. In older populations, ten studies were conducted in regional areas but again it has been shown that prevalence may vary by region within a country. ${ }^{[93]}$ Only one study of an older population used a sample claimed to be representative of the general elderly population. ${ }^{[82]}$ Inclusion of census data for the countries studied would demonstrate the representativeness of samples when compared to national data.

ISSN 2377-9306 E-ISSN 2377-9330 
Table 4. Range of constipation prevalence estimates by factor in older adult populations

\begin{tabular}{|c|c|c|c|c|}
\hline Factor & Variable & $\begin{array}{l}\text { Number of } \\
\text { studies }\end{array}$ & $\begin{array}{l}\text { Lowest prevalence } \\
\text { reported (\%) }\end{array}$ & $\begin{array}{l}\text { Highest prevalence } \\
\text { reported }(\%)\end{array}$ \\
\hline \multirow{7}{*}{ Definition of constipation $\wedge$} & $<3 B M /$ week & 3 & 4.4 & 29.2 \\
\hline & Rome I & 2 & 11.6 & 24.4 \\
\hline & Rome II & 2 & 24.4 & 25.8 \\
\hline & Rome III & 4 & 4.0 & 33.9 \\
\hline & Self-report (1 month) & 1 & N/A & 22.0 \\
\hline & Self-report (12 months) & 2 & 5.7 & 40.1 \\
\hline & Self-report (NTP) & 6 & 12.3 & 44.5 \\
\hline \multirow{3}{*}{ Data collection method } & Face-to-face interview & 13 & 4.0 & 44.5 \\
\hline & Mail survey & 3 & 4.4 & 40.1 \\
\hline & Written questionnaire & 1 & N/A & 22.0 \\
\hline \multirow{4}{*}{ Age range (years) } & $\geq 50$ & 2 & 4.4 & 11.8 \\
\hline & $\geq 60$ & 4 & 4.0 & 25.8 \\
\hline & $\geq 65$ & 10 & 12.3 & 44.5 \\
\hline & $\geq 70$ & 1 & N/A & 22.8 \\
\hline \multirow{6}{*}{ Sample size } & $100-499$ & 8 & 4.0 & 44.5 \\
\hline & $500-999$ & 4 & 4.4 & 24.4 \\
\hline & $1,000-1,999$ & 1 & N/A & 40.1 \\
\hline & $2,000-4,999$ & 2 & 11.6 & 22.6 \\
\hline & $5,000-9,999$ & 1 & N/A & 11.8 \\
\hline & $>10,000$ & 1 & N/A & 5.7 \\
\hline
\end{tabular}

Note. $\mathrm{BM} /$ week $=$ Bowel movements per week, $\mathrm{NTP}=$ no time period specified, $\wedge$ More than one definition used in 3 studies

\subsubsection{Age range}

In the majority of studies in general adult populations, the lowest age has been 18 years with either no restriction on the highest age or a specific age as the highest limit (see Table 3 ). This is presumably because in most countries 18 years is the minimum adult age. Specific age ranges have been used in some studies but generally no explanations have been given as to why particular age ranges were selected. In some studies, participants over 60,65 or 70 years have been excluded. No distinct trends in prevalence by age range of samples can be identified. In older populations, the majority of studies (10 of the 17 studies) have used 65 years as the lower age limit presumably because this is generally accepted as the age of retirement in most countries (see Table 4).

\section{Conclusion}

Constipation prevalence estimates in community-dwelling adults and older adults vary by up to twentyfold in the studies included in this review. This wide range of prevalence may be attributed to several factors. The most salient factor is that different definitions have been used for both chronic and any constipation. Different data collection methods may also play a role as well as differences in sampling, apart from any inherent country or regional differences. To quantify the impact of a range of different definitions on prevalence estimates, further studies of different definitions using the same population sample are needed. This will help determine recommended definitions for use in future epidemiological studies.

Whilst it might appear that definitions based on Rome criteria would be best for chronic constipation, these criteria have not always been used in epidemiological research ${ }^{[94]}$ and when they are used, they have often been modified. Nevertheless, universally accepted standard definitions are needed for both chronic constipation and any constipation. Although the most commonly used definition for any constipation has been self-report over a period of 12 months, research is required to establish the best definition to be used as a standard. Apart from standard definitions, there are other factors to consider in future epidemiological studies. For data collection, online surveys provide efficiency and anonymity, and can provide nationally representative samples. Sample size calculations should always be provided to ensure that samples are at least the minimum size required.

If standard definitions can be agreed and used along with appropriate sampling and data collection methods, more precise estimates of constipation prevalence should be attained with less variance. This would allow more meaningful comparisons between countries and may also provide the ability to pool results. 


\section{ACKNOWLEDGeMENTS}

The author acknowledges input and guidance received from Associate Professor Lisa Pont and Professor Kylie Williams, University of Technology Sydney, and Associate Professor Murray Fisher, University of Sydney.

\section{CONFLICTS OF INTEREST DisClOSURE}

The author declares no conflict of interest regarding publication of this review.

\section{REFERENCES}

[1] Talley NJ. Definitions, epidemiology, and impact of chronic constipation. Rev Gastroenterol Disord. 2004; 4(Suppl.2): S3-S10. PMid:15184814.

[2] Dennison C, Prasad M, Lloyd A, et al. The health-related quality of life and economic burden of constipation. Pharmacoeconomics. 2005; 23(5): 461-76. PMid:15896098. https ://doi .org/10.216 5/00019053-200523050-00006

[3] Mugie SM, Benninga MA, Di Lorenzo C. Epidemiology of constipation in children and adults: a systematic review. Best Pract Res Clin Gastroenterol. 2011; 25(1): 3-18. PMid:21382575. https : //doi.org/10.1016/j.bpg. 2010.12.010

[4] Suares NC, Ford AC. Prevalence of, and risk factors for, chronic idiopathic constipation in the community: systematic review and meta-analysis. Am J Gastroenterol. 2011; 106(9): 1582-91. PMid:21606976. https ://doi .org/10.1038/ajg. 2011.164

[5] Drossman DA. Functional gastrointestinal disorders: History, pathophysiology, clinical features, and Rome IV. Gastroenterology. 2016; 150(6): 1262-79. PMid:27144617. https://doi.org/10.1053/ j.gastro.2016.02.032

[6] Singh S, Bajorek B. Pharmacotherapy in the ageing patient: The impact of age per se. Ageing Res Rev. 2015; Part B. 24: 99-110.

[7] Grant MJ, Booth A. A typology of reviews: An analysis of 14 review types and associated methodologies. Health Info Libr J. 2009; 26(2): 91-108. PMid:19490148. https://doi.org/10.1111/j. 1471-1842.2009.00848. $\mathrm{x}$

[8] Schmidt FM, Santos VL. Prevalence of constipation in the general adult population: an integrative review. J Wound Ostomy Continence Nurs. 2014; 41(1): 70-6. PMid:24378694. https ://doi .org/10 $.1097 / 01$.WON .0000438019.21229.b7

[9] Higgins PD, Johanson JF. Epidemiology of constipation in North America: a systematic review. Am J Gastroenterol. 2004; 99(4): 7509. PMid:15089911. https://doi.org/10.1111/j.1572-0241. 2004.04114.x

[10] Hammond EC. Some Preliminary Findings on Physical Complaints from a Prospective Study of 1,064,004 Men and Women. Am J Public Health Nations Health. 1964; 54: 11-23. PMid:14117648. https://doi.org/10.2105/AJPH. 54.1.11

[11] Talley NJ, Zinsmeister AR, Van Dyke C, Melton LJ, 3rd. Epidemiology of colonic symptoms and the irritable bowel syndrome. Gastroenterology. 1991; 101(4): 927-34. https://doi.org/10.101 6/0016-5085 (91) 90717-Y

[12] Talley NJ, Weaver AL, Zinsmeister AR, Melton LJ, 3rd. Functional constipation and outlet delay: a population-based study. Gastroenterology. 1993; 105(3): 781-90. https://doi.org/10.1016/00 $16-5085$ (93) $90896-\mathrm{K}$

[13] Drossman DA, Li Z, Andruzzi E, et al. U.S. householder survey of functional gastrointestinal disorders. Prevalence, sociodemography, and health impact. Dig Dis Sci. 1993; 38(9): 1569-80. PMid:8359066. https://doi.org/10.1007/BF01303162
[14] Pare P, Ferrazzi S, Thompson WG, et al. An epidemiological survey of constipation in Canada: Definitions, rates, demographics, and predictors of health care seeking. Am J Gastroenterol. 2001; 96(11): 3130-7. PMid:11721760. https://doi.org/10.1111/j . 1572-0241.2001.05259.x

[15] Sandler RS, Jordan MC, Shelton BJ. Demographic and dietary determinants of constipation in the US population. Am J Public Health. 1990; 80(2): 185-9. PMid:2297063. https://doi.org/10.2105/ AJPH. 80.2.185

[16] Everhart JE, Go VL, Johannes RS, et al. A longitudinal survey of self-reported bowel habits in the United States. Dig Dis Sci. 1989; 34(8): 1153-62. PMid:2787735. https://doi .org/10.1007/BF 01537261

[17] Harari D, Gurwitz JH, Avorn J, et al. Bowel habit in relation to age and gender. Findings from the National Health Interview Survey and clinical implications. Arch Intern Med. 1996; 156(3): 315 20. PMid:8572842. https://doi .org/10.1001/archinte. 199 6.00440030117014

[18] Johanson JF, Sonnenberg A, Koch TR. Clinical epidemiology of chronic constipation. J Clin Gastroenterol. 1989; 11(5): 525-36. PMid:2551954. https://doi.org/10.1097/00004836-19891 0000-00008

[19] Stewart WF, Liberman JN, Sandler RS, et al. Epidemiology of constipation (EPOC) study in the United States: relation of clinical subtypes to sociodemographic features. Am J Gastroenterol. 1999; 94(12): 3530-40. PMid:10606315. https://doi.org/10.1111/ j.1572-0241.1999.01642.x

[20] Chang JY, Locke GR, Schleck CD, et al. Risk factors for chronic constipation and a possible role of analgesics. Neurogastroenterol Motil. 2007; 19(11): 905-11. PMid:17988275. https ://doi.org/ 10.1111/j.1365-2982.2007.00974.x

[21] Choung RS, Locke GR, Zinsmeister AR, et al. Alternating bowel pattern: what do people mean? Aliment Pharmacol Ther. 2006; 23(12): 1749-55. PMid:16817919. https://doi.org/10.1111/j.1365 $-2036.2006 .02953 . \mathrm{x}$

[22] Tuteja AK, Talley NJ, Joos SK, et al. Is constipation associated with decreased physical activity in normally active subjects? Am J Gastroenterol. 2005; 100(1): 124-9. PMid:15654791. https : //doi.org/10.1111/j.1572-0241.2005.40516.x

[23] Johanson JF, Kralstein J. Chronic constipation: a survey of the patient perspective. Aliment Pharmacol Ther. 2007; 25(5): 599-608. PMid:17305761. https://doi.org/10.1111/j.1365-2036. 20 $06.03238 . x$

[24] Wald A, Scarpignato C, Mueller-Lissner S, et al. A multinational survey of prevalence and patterns of laxative use among adults with self-defined constipation. Aliment Pharmacol Ther. 2008; 28(7): 917 30. https://doi.org/10.1111/j.1365-2036.2008.03806.x

[25] Choung RS, Rey E, Locke GR, et al. Chronic constipation and comorbidities: A prospective population-based nested case-control study. United European Gastroenterol J. 2016; 4(1): 142-51. 
PMid:26966534. https ://doi.org/10.1177/20506406145584 76

[26] Markland AD, Palsson O, Goode PS, et al. Association of low dietary intake of fiber and liquids with constipation: evidence from the National Health and Nutrition Examination Survey. Am J Gastroenterol. 2013; 108(5): 796-803. PMid:23567352. https : //doi.org/10.1038/ajg.2013.73

[27] Heidelbaugh JJ, Stelwagon M, Miller SA, et al. The spectrum of constipation-predominant irritable bowel syndrome and chronic idiopathic constipation: US survey assessing symptoms, care seeking, and disease burden. Am J Gastroenterol. 2015; 110(4): 580-7. PMid:25781368. https ://doi .org/10.1038/ajg. 2015.67

[28] Palsson OS, Whitehead WE, Van Tilburg MAL, et al. Development and validation of the Rome IV diagnostic questionnaire for adults. Gastroenterology. 2016; 150(6): 1481-91. PMid:27144634 https://doi.org/10.1053/j.gastro.2016.02.014

[29] Halder SLS, Locke GR, Schleck CD, et al. Natural history of functional gastrointestinal disorders: a 12-year longitudinal population-based study. Gastroenterology. 2007; 133(3): 799807. PMid:17678917 https://doi.org/10.1053/j.gastro. 2 007.06 .010

[30] Choung RS, Locke GR, Rey E, et al. Factors associated with persistent and nonpersistent chronic constipation, over 20 years. Clin Gastroenterol Hepatol. 2012; 10(5): 494-500. PMid:22289877. https://doi.org/10.1016/j.cgh.2011.12.041

[31] Peppas G, Alexiou VG, Mourtzoukou E, et al. Epidemiology of constipation in Europe and Oceania: a systematic review. BMC Gastroenterol. 2008; 8(5). https ://doi .org/10.1186/1471-230X-8-5

[32] Walter S, Hallbook O, Gotthard R, et al. A population-based study on bowel habits in a Swedish community: prevalence of faecal incontinence and constipation. Scand J Gastroenterol. 2002; 37(8): 911-6. PMid:12229965. https ://doi.org/10.1080/00365520276023 0865

[33] Haug TT, Mykletun A, Dahl AA. Are anxiety and depression related to gastrointestinal symptoms in the general population? Scand J Gastroenterol. 2002; 37(3): 294-8. PMid:11916191. https ://doi. org/10.1080/003655202317284192

[34] Siproudhis L, Pigot F, Godeberge P, et al. Defecation disorders: a French population survey. Dis Colon Rectum. 2006; 49(2): 21927. PMid:16362804. https://doi.org/10.1007/s10350-005 $-0249-8$

[35] Garrigues V, Galvez C, Ortiz V, et al. Prevalence of constipation: agreement among several criteria and evaluation of the diagnostic accuracy of qualifying symptoms and self-reported definition in a population-based survey in Spain. Am J Epidemiol. 2004; 159(5): 520-6. PMid:14977649. https : //doi.org/10.1093/aje/kwh0 72

[36] Bassotti G, Bellini M, Pucciani F, et al. An extended assessment of bowel habits in a general population. World J Gastroenterol. 2004; 10(5): 713-6. PMid:14991944. https : //doi .org/10.3748/wjg. v10.i5.713

[37] Fosnes GS, Lydersen S, Farup PG. Constipation and diarrhoea - common adverse drug reactions? A cross sectional study in the general population. BMC Clin Pharmacol. 2011; 11. https: //doi.org/10.1186/1472-6904-11-2

[38] van Kerkhoven LAS, Eikendal T, Laheij RJF, et al. Gastrointestinal symptoms are still common in a general Western population. Neth $\mathrm{J}$ Med. 2008; 66(1): 18-22. PMid:18219063.

[39] Meinds RJ, van Meegdenburg MM, Trzpis M, et al. On the prevalence of constipation and fecal incontinence, and their cooccurrence, in the Netherlands. Int J Colorectal Dis. 2017; 32(4):
475-83. PMid:27913883. https : //doi .org/10.1007/s00384-0 16-2722-3

[40] Enck P, Leinert J, Smid M, et al. Prevalence of constipation in the German population-a representative survey (GECCO). United European Gastroenterol J. 2016; 4(3): 429-37. PMid:27403310. https://doi.org/10.1177/2050640615603009

[41] Papatheodoridis GV, Vlachogiannakos J, Karaitianos I, et al. A Greek survey of community prevalence and characteristics of constipation. Eur J Gastroenterol Hepatol. 2010; 22(3): 354-60. PMid:19474747. https : //doi.org/10.1097/MEG.0b013e32832bfdf0

[42] Pamuk ON, Pamuk GE, Celik AF. Revalidation of description of constipation in terms of recall bias and visual scale analog questionnaire. J Gastroenterol Hepatol. 2003; 18(12): 1417-22. PMid:14675272. https://doi.org/10.1046/j.1440-1746.2003.03155.x

[43] Ebling B, Gulic S, Jurcic D, et al. Demographic, anthropometric and socioeconomic characteristics of functional constipation in Eastern Croatia. Coll Antropol. 2014; 38(2): 539-46. PMid:25144985.

[44] Esteban Y, Pena M, Garcia RJ, et al. Impact of the most frequent chronic health conditions on the quality of life among people aged > 15 years in Madrid. Eur J Public Health. 2010; 20(1): 78-84. PMid:19587225. https : //doi.org/10.1093/eurpub/ckp098

[45] Rey E, Balboa A, Mearin F. Chronic constipation, irritable bowel syndrome with constipation and constipation with pain/discomfort: similarities and differences. Am J Gastroenterol. 2014; 109(6): 87684. PMid:24589666. https ://doi .org/10.1038/ajg. 2014.18

[46] Tamura A, Tomita T, Oshima T, et al. Prevalence and self-recognition of chronic constipation: Results of an internet survey. J Neurogastroenterol Motil. 2016; 22(4): 677-85. PMid:27426278. https : //doi.org/10.5056/jnm15187

[47] Chen LY, Ho KY, Phua KH. Normal bowel habits and prevalence of functional bowel disorders in Singaporean adults-findings from a community based study in Bishan. Singapore Med J. 2000; 41(6): 255-8. PMid:11109339.

[48] Ho KY, Kang JY, Seow A. Prevalence of gastrointestinal symptoms in a multiracial Asian population, with particular reference to reflux-type symptoms. Am J Gastroenterol. 1998; 93(10): 181622. PMid:9772037. https://doi.org/10.1111/j.1572-0241. 1998.00526. $\mathrm{x}$

[49] Chang FY, Chen PH, Wu TC, et al. Prevalence of functional gastrointestinal disorders in Taiwan: questionnaire-based survey for adults based on the Rome III criteria. Asia Pacific J Clin Nutr. 2012; 21(4): 594-600. PMid:23017318.

[50] Lu CL, Chang FY, Chen CY, et al. Significance of Rome II-defined functional constipation in Taiwan and comparison with constipationpredominant irritable bowel syndrome. Aliment Pharmacol Ther. 2006; 24(2): 429-38. PMid:16842471. https ://doi .org/10.111 $1 / j .1365-2036.2006 .02949 . x$

[51] Jun DW, Park HY, Lee OY, et al. A population-based study on bowel habits in a Korean community: prevalence of functional constipation and self-reported constipation. Dig Dis Sci. 2006; 51(8): 14717. PMid:16832618. https://doi.org/10.1007/s10620-006-9 087-3

[52] Jeong JJ, Choi MG, Cho YS, et al. Chronic gastrointestinal symptoms and quality of life in the Korean population. World J Gastroenterol. 2008; 14(41): 6388-94. PMid:19009657. https ://doi.org/10.3 $748 /$ wjg. 14.6388

[53] Wald A, Mueller-Lissner S, Kamm MA, et al. Survey of laxative use by adults with self-defined constipation in South America and Asia: a comparison of six countries. Aliment Pharmacol Ther. 2010; 31(2): 274-84. PMid:19832728.

[54] Cheng C, Chan AOO, Hui WM, et al. Coping strategies, illness perception, anxiety and depression of patients with idiopathic con- 
stipation: a population-based study. Aliment Pharmacol Ther. 2003; 18(3): 319-26. PMid:12895216. https://doi.org/10.1046/j . 1365-2036.2003.01663.x

[55] Adibi P, Behzad E, Pirzadeh S, et al. Bowel habit reference values and abnormalities in young Iranian healthy adults. Dig Dis Sci. 2007 52(8): 1810-3. PMid:17410463. https://doi.org/10.1007/s1 0620-006-9509-2

[56] Sorouri M, Pourhoseingholi MA, Vahedi M, et al. Functional bowel disorders in Iranian population using Rome III criteria. Saudi J Gastroenterol. 2010; 16(3): 154-60. PMid:20616409. https://doi.or g/10.4103/1319-3767.65183

[57] Moezi P, Salehi A, Molavi H, et al. Prevalence of chronic constipation and its associated factors in pars cohort study: A study of 9000 adults in Southern Iran. Middle East J Dig Dis. 2018; 10(2): 75-83. PMid:30013755. https://doi.org/10.15171/mejdd.2018.94

[58] Rajput M, Kumari Saini S. Prevalence of Constipation Among the General Population. Gastroenterol Nurs. 2014; 37(6): 425-9. PMid:25461464. https://doi.org/10.1097/SGA.0000000000 000074

[59] Herz MJ, Kahan E, Zalevski S, et al. Constipation: a different entity for patients and doctors. Family Practice. 1996; 13(2): 156-9. PMid:8732327. https ://doi .org/10.1093/fampra/13.2.156

[60] Chu H, Zhong L, Li H, et al. Epidemiology characteristics of constipation for general population, pediatric population, and elderly population in China. Gastroenterol Res Pract. 2014; 2014 (no pagination)(532734).

[61] Iraji N, Keshteli AH, Sadeghpour S, et al. Constipation in Iran: Sepahan systematic review no. 5. Int J Prev Med. 2012; 3(4) PMid:22826768.

[62] Chinzon D, Dias-Bastos TRP, Medeiros da Silva A, et al. Epidemiology of constipation in Sao Paulo, Brazil: a population-based study. Curr Med Res Opinion. 2015; 31(1): 57-64. PMid:25295483. https://doi.org/10.1185/03007995.2014.973485

[63] Schmidt FM, de Gouveia Santos VL, de Cassia Domansky R, et al Constipation: Prevalence and Associated Factors in Adults Living in Londrina, Southern Brazil. Gastroenterol Nurs. 2016; 39(3): 204-11. PMid:27258460. https ://doi.org/10.1097/SGA.0000000000 000224

[64] Ng KS, Nassar N, Hamd K, et al. Prevalence of functional bowel disorders and faecal incontinence: An Australian primary care survey. Colorectal Dis. 2015; 17(2): 150-9. PMid:25359460. https : //doi.org/10.1111/codi.12808

[65] Koloski NA, Jones M, Young M, et al. Differentiation of functional constipation and constipation predominant irritable bowel syndrome based on Rome III criteria: a population-based study. Aliment Pharmacol Ther. 2015; 41(9): 856-66. PMid:25736433. https://doi.org/10.1111/apt.13149

[66] Bytzer P, Howell S, Leemon M, et al. Low socioeconomic class is a risk factor for upper and lower gastrointestinal symptoms: a population based study in 15000 Australian adults. Gut. 2001; 49(1): 66-72. PMid:11413112. https://doi.org/10.1136/gut.49.1.66

[67] Boyce PM, Talley NJ, Burke C, et al. Epidemiology of the functional gastrointestinal disorders diagnosed according to Rome II criteria: An Australian population-based study. Int Med J. 2006; 36(1): 28-36. PMid:16409310. https://doi.org/10.1111/j.1445-5994.20 $06.01006 . \mathrm{x}$

[68] Koloski NA, Talley NJ, Boyce PM. Epidemiology and health care seeking in the functional GI disorders: a population-based study. Am J Gastroenterol. 2002; 97(9): 2290-9. PMid:12358247. https : //doi.org/10.1111/j.1572-0241.2002.05783.x

[69] Talley NJ, Boyce P, Jones M. Identification of distinct upper and lower gastrointestinal symptom groupings in an urban population.
Gut. 1998; 42(5): 690-5. PMid:9659166. https ://doi .org/10.1 $136 /$ gut. 42.5 .690

[70] Lam TCF, Kennedy ML, Chen FC, et al. Prevalence of faecal incontinence: obstetric and constipation-related risk factors; a populationbased study. Colorectal Dis. 1999; 1(4): 197-203. PMid:23577806. https://doi.org/10.1046/j.1463-1318.1999.00044.x

[71] Howell SC, Quine S, Talley NJ. Low social class is linked to upper gastrointestinal symptoms in an Australian sample of urban adults. Scand J Gastroenterol. 2006; 41(6): 657-66. PMid:16716963. https ://doi.org/10.1080/00365520500442567

[72] Suyasa IGPD, Paterson JB, Xiao LD, et al. Prevalence of constipation in communitydwelling older people in Indonesia. J Gastroenterol Hepatol. 2011; 4: 84.

[73] Song HJ. Constipation in community-dwelling elders: Prevalence and associated factors. J Wound Ostomy Continence Nurs. 2012; 39(6): 640-5. PMid:22948493. https : //doi.org/10.1097/WON. Ob013e31826a4b70

[74] Lopez Cara MA, Tarraga Lopez PJ, Cerdan Oliver M, et al. Constipation in the population over 50 years of age in Albacete province. Rev Esp Enferm Dig. 2006; 98(6): 449-59. PMid:16948544. https : //doi.org/10.4321/S1130-01082006000600006

[75] Andy UU, Vaughan CP, Burgio KL, et al. Shared Risk Factors for Constipation, Fecal Incontinence, and Combined Symptoms in Older U.S. Adults. J Am Geriatr Soc. 2016; 64(11): e183-e8. PMid:27783401. https ://doi.org/10.1111/jgs. 14521

[76] Wolfsen CR, Barker JC, Mitteness LS. Constipation in the daily lives of frail elderly people. Arch Fam Med. 1993; 2(8): 8538. PMid:8111515. https://doi.org/10.1001/archfami.2.8 .853

[77] Chaplin A, Curless R, Thomson R, et al. Prevalence of lower gastrointestinal symptoms and associated consultation behaviour in a British elderly population determined by face-to-face interview. Brit J Gen Pract. 2000; 50(459): 798-802. PMid:11127169.

[78] Pit SW, Byles JE, Cockburn J. Prevalence of self-reported risk factors for medication misadventure among older people in general practice. J Eval Clin Pract. 2008; 14(2): 203-8. PMid:18284523. https://doi.org/10.1111/j.1365-2753.2007.00833.x

[79] Werth BL, Williams KA, Pont LG. A longitudinal study of constipation and laxative use in a community-dwelling elderly population. Arch Gerontol Geriatr. 2015; 60(3): 418-24. PMid:25736738. https://doi.org/10.1016/j.archger.2015.02.004

[80] Fragakis A, Zhou J, Mannan H, et al. Association between Drug Usage and Constipation in the Elderly Population of Greater Western Sydney Australia. Int J Environ Res Public Health. 2018; 15(2). PMid:29382180. https ://doi .org/10.3390/ijerph15020226

[81] Meiring PJ, Joubert G. Constipation in elderly patients attending a polyclinic. South African Med J. 1998; 88(7): 888-90. PMid:9698719.

[82] Wong ML, Wee S, Pin CH, et al. Sociodemographic and lifestyle factors associated with constipation in an elderly Asian community. Am J Gastroenterol. 1999; 94(5): 1283-91. PMid:10235208. https ://doi.org/10.1111/j.1572-0241.1999.01078.x

[83] Harari D, Gurwitz JH, Avorn J, et al. How do older persons define constipation? Implications for therapeutic management. J Gen Internal Med. 1997; 12(1): 63-6. https ://doi.org/10.1007/s11606 -006-0009-z

[84] Talley NJ, Fleming KC, Evans JM, et al. Constipation in an elderly community: a study of prevalence and potential risk factors. Am J Gastroenterol. 1996; 91(1): 19-25. PMid:8561137.

[85] Stewart RB, Moore MT, Marks RG, et al. Correlates of constipation in an ambulatory elderly population. Am J Gastroenterol. 1992; 87(7): 859-64. PMid:1615939. 
[86] Whitehead WE, Drinkwater D, Cheskin LJ, et al. Constipation in the elderly living at home. Definition, prevalence, and relationship to lifestyle and health status. J Am Geriatr Soc. 1989; 37(5): 423-9. PMid:2539405. https://doi.org/10.1111/j.1532-5415.19 89. tb02638. $\mathrm{x}$

[87] Lindeman RD, Romero LJ, Liang HC, et al. Do elderly persons need to be encouraged to drink more fluids? J Gerontol A Biol Sci Medl Sci. 2000; 55(7): M361-5.

[88] Campbell AJ, Busby WJ, Horwath CC. Factors associated with constipation in a community based sample of people aged 70 years and over. J Epidemiol Community Health. 1993; 47(1): 23-6. PMid:8382251. https://doi.org/10.1136/jech.47.1.23

[89] Wong RK, Palsson OS, Turner MJ, et al. Inability of the Rome III criteria to distinguish functional constipation from constipationsubtype irritable bowel syndrome. Am J Gastroenterol. 2010; 105(10): 2228-34. PMid:20502449. https ://doi.org/10.1038/ajg. 20 10. 200

[90] Ford AC, Bercik P, Morgan DG, et al. Characteristics of functional bowel disorder patients: A cross-sectional survey using the
Rome III criteria. Aliment Pharmacol Ther. 2014; 39(3): 312-21. PMid:24308816. https : //doi.org/10.1111/apt.12573

[91] Siah KTH, Wong RK, Whitehead WE. Chronic constipation and constipation-predominant IBS: Separate and distinct disorders or a spectrum of disease? Gastroenterol Hepatol. 2016; 12(3): 171-8.

[92] Aziz I, Palsson OS, Tornblom H, et al. The prevalence and impact of overlapping Rome IV-diagnosed functional gastrointestinal disorders on somatization, quality of life, and healthcare utilization: A cross-sectional general population study in three countries. Am J Gastroenterol. 2018; 113(1): 86-96. PMid:29134969. https ://doi.org/10.1038/ajg.2017.421

[93] Johanson JF. Geographic distribution of constipation in the United States. Am J Gastroenterol. 1998; 93(2): 188-91. PMid:9468239. https ://doi.org/10.1111/j.1572-0241.1998.00188.x

[94] Lacy BE, Mearin F, Chang L, et al. Bowel disorders. Gastroenterology. 2016; 150(6): 1393-407. PMid:27144627. https://doi.org/ $10.1053 /$ j.gastro.2016.02.031 